\title{
MERKEZİ OTORİTE KARŞISINDA BİR DAĞLI EŞKIYASI: DELİ KADRI
}

\section{ONE MOUNTAIN BANDIT AGAINST CENTRAL AUTHORITY: DELI KADRI}

Eyyub ŞİMŞEK ${ }^{*}$

\begin{abstract}
$\ddot{O} z$
Dağlı eşkıyalarının Rumeli'yi kasıp kavurduğu dönemde Bergos civarında pek de meşhur olmayan Deli Kadri adlı bir eşkıya faaliyette bulunmaktaydı. Deli Kadri'nin politik arzulardan uzak, yă̆macılı̆̆a dayal faaliyetleri onu sıradan bir eşkıya yapmaktaydı. Belki de bu yüzden tarihçilerin dikkatini çekememişti. Hâlbuki Osmanl imparatorluğunun onun gibi sıradan bir eşkıya ile mücadelesi devletin eşkıyaya yönelik siyasetinin belirlenmesinde önemli ipuçları verebilmektedir. Bu çalışma, onun devlet ile olan ilişkileri aracılı̆̆ıyla dönemin portresine bir katkı sağlamayı amaçlamaktadır. Başbakanlık Osmanlı Arşivi'ne dayanılarak yapılan bu çalışmada bir eşkııanın merkezi otoriteyi nasıl uğraştırdığı ortaya konulmaya çalışılırken, diğer taraftan devletin eşkıyalara yönelik izlediği politikalar ele alınarak değerlendirilmeye çalışılacaktır.
\end{abstract}

\section{Anahtar Kelimeler}

Osmanlı, Dağhı Eşkıyası, Deli Kadri, Bergos.

\begin{abstract}
During the time when the mountainous bandits terrorised Rumelia, a bandit called Deli Kadri, who was not that famous around Bergos, was doing banditry activities. The activities of Deli Kadri which were based on looting and were far from political ambitions made him an ordinary bandit. Maybe that's why he didn't grab the attention of historians. However, the struggle of the Ottoman Empire with an ordinary bandit like him can give important clues about the empire's policy towards the banditry. This study aims to contribute to the portrait of the period through his relations with the state. In this study, based on the Ottoman Archives, it will be tried to determine how a bandit cause a lot of trouble to the central authority, and on the other hand, the policies of the empire towards the bandits will be evaluated.

\section{Keywords}

Ottoman, mountainous bandit, Deli Kadri, Bergos.
\end{abstract}

* Dr. Öğr. Üyesi, Aksaray Fen-Edebiyat Fakültesi Tarih Bölümü, eyyubsimsek@aksaray.edu.tr 


\section{Giriş}

III. Selim dönemi (1789-1807) Osmanlı İmparatorluğu tarihinde isyanların en yoğun olduğu dönemlerden birisi olarak bilinir: Rumeli'deki eşkıya isyanları, Arabistan'daki Vehhabi hareketi, Mısır'daki isyanlar ve Sırp isyanları (Beydilli 2009: 422). Bunlar içerisinde "dağlı eşkıyaları" olarak bilinen ve imparatorluğun Balkan coğrafyasını onlarca yıl kasıp kavuran isyanlar, özelde III. Selim dönemi ile özdeşleşmiştir. ${ }^{1}$ Gerçekten ilk defa Rumeli'de Kırcaali dağlarında ortaya çıkan bu sebeple "dağlı eşkıyaları" olarak anılmış olan eşkıyalar, kendilerine yeni katılımlarla giderek çoğalmışlar ve zamanla bütün Balkan coğrafyasını etkileri altına almışlardır. Yılıkoğlu Süleyman, Tirsinikli İsmail (Uzunçarşılı 2010), Pazvandoğlu (Beydilli 2007: 208-210; Yavuz 2010) Gümülcine ayanı Tokadcıklı Süleyman (Aygün 2010: 707-768) vb. eşkıyalar III. Selim'in saltanatı boyunca merkezi otoriteyi uğraştırmışlardı (Özkaya 1983: 7). Rusya ile yapılan ve ağır mağlubiyetlerle neticelenen 1768-1774 ve 1787-1792 savaşlarına ev sahipliği yapan Balkan coğrafyası bu mücadelelerin yükünü çekmek zorunda kalmış, ağır vergiler yöneticilerin zulmü ile birleşince bölgede sosyal ve ekonomik çalkantılar kaçınılmaz hale gelmişti. Bu dönemde imparatorluğun meşgul olduğu iki büyük sorun bulunmaktaydı: İçeride reform, dışarıda ise Fransa ile Rusya arasındaki denge arayışı (Yaycıoğlu 2015). Dolayısıyla Kırcaali dağlarında başlayan eşkıyalık hareketleri aslında devletin içerisinde bulunduğu şartlara da isyan niteliğinde idi ve bu isyan uzun bir süre etkisini kaybetmedi. Devletin otorite boşluğu, ayanların gittikçe güçlenen nüfuzları ile ikame edilirken; ayanlar bu güçlerini, devlet adına kullanmak yerine kendi bölgelerini korumayı öncelemişlerdi (Nagata 1997; Aynı Yazar 1999; Özkaya 2014). Hatta eşkıyayı koruyan bir tutum sergiliyorlardı (Karal 1942: 115-117; İlgürel 1995: 468). Bu durum Balkanları eşkıya için mümbit bir bölge haline getiriyordu.

Bu çalışmaya konu olan dağlı eşkıyalarından Deli Kadri'nin yaşadığı bölge olan Bergos ya da Burgaz, bugün Bulgaristan sınırları içerisinde, Karadeniz sahilinde yer alan bir şehirdir. Konunun işlendiği, 18. Yüzyılın sonu ve 19. Yüzyılın başında Bergos, Edirne Vilayeti'ne tabi Tekfurdağı Kazasının bir kasabası durumundaydı. Kasabanın limanı, başkentin iaşesi için stratejik bir öneme sahipti. İstanbul'a Balkanlar ve Kırım tarafından gelen zahire, Bergos limanı üzerinden payitahta ulaştııılmaktaydı. Yani belgelerin diliyle ifade edilecek olursa Bergos, İstanbul'un kileri mesabesinde (BOA.C.AS. 192-8280) bir yerdi. Diğer taraftan Bergos, Karadeniz sahilinde gemi yapımının olduğu önemli bir tersaneye sahipti (Ekinci 2013: 24). Bergos'un küçük ama önemli bir kasaba oluşu, burayı eşkıyalar için cazip hale getiriyordu. Sosyal ve ekonomik düzenin bozulduğu 1790'lı yıllarda eşkıyanın sıkça uğradığı bir bölge olmuştu. Bergos-Kırkkilise arasındaki yol, "eşkıya yată̆ı" olarak nam salmış bir bölgeydi. Özellikle limana zahire götüren arabalar, eşkıyanın hedefi haline gelmekteydi (BOA.AE.SABH.I. 1369178; AE.SSLM.III 142-8573; C.ZB. 8-368). Bölgenin etrafı eşkıya ile dolu iken, bölge halkı içerisinden de eşkıyalar çıkmaktaydı. Bu çalışmada Bergos'tan çıkan bir eşkıyanın "Deli" lakabiyla bir dönem Balkanlar'da korku salan Kadri'nin faaliyetleri üzerinde durularak, Osmanlı İmparatorluğunun bir dağlı eşkıyasını neden yakalayamadığı sorusuna cevap aranacaktır. Böylece buradan çıarılacak sonuçların dönemin genel portresine bir katkı yapması amaçlanmaktadır. Bu çalışmanın temel kaynağını Başbakanlık Osmanlı Arşivi'nde yer alan HAT tasnifleri oluşturmaktadır. Bu tasnifin yanında Şeriye Sicilleri ve Mühimme defterlerine de başvurulmuştur. Bu iki kaynak, verdikleri bilgilerin yanında HAT tasniflerinde bulunup da

İsyanlar, III. Selim'in iktidarını kaybetmesinde de önemli bir rol oynamıştır (Yıldız 2017). 
tarih verilmemiş olan belgelerin tarihlerinin de teyit edilmesi açısından da önemli bir katkı sağlamıştır. Yine Ahmet Cevdet Paşa, Câbî Ömer Efendi ve Mütercim Ahmed Âsım Efendi'nin döneme ilişkin Osmanlı Tarihi eserleri de bu çalışmada kullanılmıştır. Son olarak dönemin Fransız matbuası da taranarak elde edilen bilgiler değerlendirilmiştir.

\section{Deli Kadri'nin Ortaya Çıkışı}

III. Selim'in tahttan indirilişinden sonra idam edilen Kâhya (Kethüda) İbrahim, servetini gayr-i meşru yollarla elde etmekle itham edilmişti (Journal de l'empire, 14 Temmuz 1807). İddialara göre; Kâhya İbrahim, "dudak uçuklatan" bu serveti² dağlı eşkıyalarını koruyarak ve onların elde ettiği ganimeti paylaşarak biriktirmişti. Bu eşkıyalar arasında yer alan Pasvandoğlu birçok çalışmaya konu olmuştur. Fakat diğer eşkıya Deli Kadri ile ilgili doğrudan hiçbir çalışma bulunmamaktadır. Yaptıkları ile adını Osmanlı toprakları dışında yayımlanan gazetelerde duyuracak kadar nam salan Deli Kadri, kısa bir süreliğine de olsa (1803-1807) özellikle güney Balkanları haraca kesmiş, Osmanlı Padişahını bile çileden çıkarmıştı.

Bergos'ta doğup büyüdüğü anlaşılan Kadri, Benlizade Mehmed'in oğludur (BOA.C.DH. 303-15123). Fakat belgelerde kendisinden bahsedilirken "Deli Kadri" olarak bahsedilmiştir. Dönemin meşhur dağlı eşkıyalarından onu farklı kılan hususlardan birisi de kullanmış olduğu unvandır. Kendisi Yılıkoğlu, Tirsiniklizade örneklerinde olduğu gibi ne aile veya soyluluğa işaret olacak ne de Gümülcine Ayânı Tokadcıklı Süleyman gibi memleketini gösteren bir unvan kullanmıştır. Onun kullanmış olduğu "deli" lakabı tarihte birçok eşkıyada görülebilecek adeta geleneksel bir unvandı. Eşkıyalık onun için siyasal hedeflere ulaşmakta bir araç değil, bir yaşam biçimiydi. Cebren mala ve cana tecavüz ile kamu düzenini ve asayişi bozmak olarak tarif edilen eşkıyalığın (Bardakoğlu, 1995: 463-466) bu özelliklerine haiz olan Deli Kadri, bunun yanında kendi adamlarını rahatça feda edebilecek, geriye dönmeyi asla düşünmeyen, günü birlik yaşayan, yağmacılığı bir geçim kaynağı olarak gören, tamahkâr; ama bir o kadar da korkak bir kişiliğe de sahipti.

Deli Kadri'nin ilk ortaya çıkışı, her ne kadar 1805 yılında dağlı eşkıyasının Tekirdağ'da Osmanlı donanmasına kurşun attığı olayla başlatılsa da (Özkaya 1983: 97-98) doğrusu 1790'lı yılların sonudur; fakat namını yayışı 1803 yılının sonbahar mevsimidir. Doğup büyüdüğü Bergos'tan ayrılıp, eşkıyalığa başlamasının nedeni Bergos ayanının kendisine beslediği kin ve nefretti (MŞH.ŞSC.d 7427/136-1). İlk eşkıyalığa başladığı dönemler hakkında pek malumat bulunmamakla beraber 1795-1800 yılları arasında memleketi Bergos civarında yağma ve eşkıyalık yaptı̆̆ına dair bilgiler mevcuttur. Bu dönemde adını duyurmayı başaramayan Kadri, padişahtan affını dileyerek Bergos'ta ikâmet etmeye başlamıştı (BOA.AE.SSLM.III. 67-4042; C.ZB. 25-1215).

Rumeli'de çok sayıdaki eşkıya ile mücadelede yetersiz kalan Osmanlı İmparatorluğu, eşkıyaların affedilerek kendi bölgeleri ya da civar yerleşim birimlerine iskân ettirilmesini bir çözüm yolu olarak uygulamaktaydı (Başer, 2006). Pek de başarılı olmayan bu uygulamadan Deli Kadri ilk defa yararlandıktan sonra tabiatı gereği kısa bir süre sonra yeniden eşkıyalığa döndü. Bu ikinci döneminde Deli Kadri gerçekten adını duyurmayı başarmıştı. Onun eşkıyalık

Kâhya (Kethüda) İbrahim'in muhallefatını gören Mabeynci Ahmed Bey'in "Hâne mi, yâ cennet-i a'lâ mıdır?" şeklindeki ifadesi İbrahim'in servetinin büyüklüğünü göstermesi açısından önemlidir (Mütercim Ahmed Âsım Efendi, II, 2015: 865). 
faaliyetlerinde dönüm noktası; meşhur dağlı eşkıyası Kara Feyzi'nin ${ }^{3}$ Osmanlı askerinin eline düşmesine mani oluşu idi. Kara Feyzi'yi kurtaran adam olarak nam salan Kadri, bu vakadan sonra ilerleyen dört yıllık sürede Edirne ve civarının en azılı haydutlarından birisi haline gelecekti. Bugün Bulgaristan sınırları içerisinde yer alan ve Büyük Balkan Dağlarının eteğinde bulunan Kazanlık'ta Osmanlı askerleri Kara Feyzi'yi çembere almıştı. Yapılan iki muharebede ağır mağlubiyetler alan ve birçok adamını kaybeden Kara Feyzi için yolun sonu görünmekteydi. Edirne ve civarındaki eşkıyalık hareketlerinin ortadan kaldırılması ile görevlendirilen Serezli (Sirozlu) İsmail Ağa, Kara Feyzi'nin teslim olmaktan başka yapabileceği tek şeyin Balkan Dağlarını aşarak öte tarafta birilerinin hizmetkârlığını yapmak olacağına inanmaktaydı. Onu bu düşünceye iten şey; kuşatma esnasında eski bir eşkıya olan Molla Ali'nin de Osmanlı askerinin yardımına gelmiş olmasıydı. Fakat Bergoslu olarak bilinen ve etrafta "Deli" lakabıyla nam salmaya çalışan Kadri adlı eşkıya gerçekten de lakabına layık olurcasına Osmanlı kuşatmasını yararak, Kazanlık'a girip, Kara Feyzi'ye yardıma gelince kuşatmanın seyri birden değişiverdi. Üstelik Deli Kadri yalnız değildi; yanında Gümüşşene lakaplı bir eşkıya daha vardı. Sayıları sekiz yüze kadar varan eşkıya, Kara Feyzi'yi içinde bulunduğu kuşatmadan kurtarmayı başardı (BOA.HAT 52-2456; 218-12000; 53-2485). Bu olayın akabinde, Serezli İsmail, Deli Kadri ve Kara Feyzi ile doğrudan ilgilenmekle görevlendirildi. Serezli İsmail, Rumeli ayanları arasında devlete en bağlı olanlardan birisiydi. Kapucubaşı payesi verilmiş olan İsmail Ağa, 1808 tarihli Sened-i İttifak'ta imzası bulunan ayanlardan olup, yine ayanlar arasında en nüfuzlu olanlardandı. İleri görüşlülüğü ile bilinen İsmail Ağa, Sultan III. Selim'in emirlerini yerine getirmekte pek tereddüt etmediği gibi devlet ile bölge ayanları arasında oynadığı arabuluculuk sayesinde bu görev için padişahın teveccühünü kazanmıştı (Uzunçarşı1ı 1971: 269). Başbuğ olarak tayin edilen Serezli İsmail'in emrine Selanik Sancağ1 Mutasarrıfı Osman Paşa verildi (A.DVN.MHMd. 219/220; 219/222).

Deli Kadri, Kazanlık'tan kaçtıktan sonra Gümüşçene ile birlikte güneye, Çırpan tarafına geçti. Serezli İsmail Ağa, Deli Kadri'yi Kara Feyzi'ye olan iltihakından vazgeçirme adına kendisiyle bir görüşme yapmışsa da onu bu fikrinden caydırmayı başaramamıştı (BOA.HAT 52-2456). Bu görüşmeden sonuç elde edilemediğinden Deli Kadri ile mücadele için Edirne'de mevcut bin beş yüz asker, Serezli İsmail Ağa'nın maiyetine, Çırpan tarafına gönderildi. Bu arada Rumeli Valisi Mehmed Paşa da Kadri olayıyla bizzat ilgileneceğini Sultan III. Selim'e bildirmişti. ${ }^{4}$ Deli Kadri ve Gümüşçene Çırpan'ı tahkîm ederek; buraya yerleştiler. Kış şartlarının ağırlığı, eşkıya takibini zora sokmaktaydı. Osmanlı askerleri sadece eşkıya ile değil, sert doğa koşulları ile de mücadele etmek zorunda kalmıştı. Kış mevsimi kendisini iyiden iyiye hissettirmekteydi. Dolayısıyla Çırpan'ın etrafını çevirmek mümkün görünmüyordu. Yapılabilecek tek şey, civar bir köye yerleşerek; eşkıyayı uzaktan takibe almaktı. Zaten askerler bütün yaz eşkıya peşinde olduklarından bitap bir halde idiler. Bu yüzden askerin birçoğu kışlalarına gönderildi. Asker gerektiğinde, bu ihtiyaç, yakın bölgelerin ayanlarından temin edilecekti (BOA.HAT 53-2485). Deli Kadri ve Kara Feyzi'nin güçlerini birleştirmeleri üzerine Bender eski muhafızı Osman Paşa da Edirne'de kalmak istediğini beyan ederek; gönüllü şekilde bu mücadeleye dâhil oldu. Kasım ayının başında bir anda güçlenen eşkıya güruhu Çırpan'dan ayrılarak Tekfurdağı (Tekirdağ) tarafına doğru güney-doğu yönünde ilerledi. Önce Baba-yı

Kara Feyzi, dağlı eşkıyaları döneminde Balkan coğrafyasının en önde gelen eşkıyalarından biri idi. Eski bir sekbân olan Kara Feyzi, 1793-1823 yılları arasında tam otuz yıl boyunca bölgede yağma, soygun ve çapulculuk faaliyetlerinde bulunmuștu (Esmer 2014: 1-18).

4 Sultan III. Selim, Tirsinikli'nin askerlerinin de Kadri'nin üzerine gönderilmesini; ama mevcut askerlerle karışık bir düzende olmamalarını ve başka hadiselere meyil verilmemesini özellikle emretmişti (BOA.HAT 218-12000; 53-2485; 218-12016). 
Atik (Babaeski) ve Hayrabolu'ya, oradan da İnecik ve Tekfurdağı'na ulaşan Kadri ve Feyzi'nin amacı Malkara'yı işgal etmekti (BOA.HAT 54-2502-C).

\section{Malkara Çarpışması}

Kış şartları Osmanlı askeri birliklerini zorlasa da eşkıya için hâlâ elde edilecek ganimetler vardı. Eşkıya geçtiği yerde zorbalıklarına devam etmiş, Baba-yı Atik'ten Hayrabolu'ya geçerken köylülerin arabalarını soyup; ahalinin bir kısmını da esir almıştı (BOA.HAT 57-2618; 57-2618-C). Eşkıyalar bir süre sonra iki kola ayrıldılar. Birlikte hareket etmekten ziyade birbirlerini destekleyen bir görüntü çizen bu eşkıya grubundan Kara Feyzi Edirne'ye altı saat mesafedeki Kuleli ${ }^{5}$ köyüne; Deli Kadri ise memleketi Bergos'a, Ahiyolu köyüne doğru yöneldi (BOA.HAT 57-2615-A). 28 Ekim Cuma günü saat yedi sularında Kara Feyzi, Kuleli köyüne vardı. Deli Kadri ertesi gün, çobanların bulunduğu yeri bastı. Çobanların hem koyunları hem de paraları Deli Kadri ve adamları tarafından gasp edildi. Gece ise; etraftaki köylere baskınlar yapılarak halka korku ve dehşet salınmıştı. Deli Kadri'nin amansız saldırıları karşısında Çene köyünde toplanmaya başlayan halka, civar yerleşim yerlerinden de destek gelmiş ve sadece yetişkin erkekler değil; kadın ve çocuklar da bu kalabalığa dâhil olmuşlardı. Kalabalığın eşkıyaya saldırısı, şiddetli şekilde karşılık bulunca halk büyük bir korku ile terk-i vatan etmeye başladı. Baba-yı Atik, Hayrabolu, Kırkkilise ve Bergos'ta insanlar korkuyla iç bölgelere doğru göç etmeye başladılar (BOA.HAT 57-2618-D). Deli Kadri ise, yanında Gümüşçene ve adamları olduğu halde, Malkara'ya yönelmişti. Eşkıyanın kasaba merkezine doğru yöneldiğini haber alan ayandan Kara Ahmed Haseki, elli altmış kadar adamıyla, kasabanın hemen dışında eşkıyanın karşısına çıktı. 31 Ekim'deki çatışma, sabahtan akşama kadar devam etmiş; eşkıya iki defa püskürtülmüşse de karanlığın bastırmasıyla Ahmed Haseki kasaba merkezine dönmek zorunda kalmıştı. Deli Kadri, gecenin karanlığından faydalanarak Malkara'nın Ermeni mahallesi tarafından saldırıya geçti. Mahalleyi yakıp, yıkan Kadri, Ahmed Haseki'nin konağını ele geçirdi. Ahmed Haseki ve yanındakileri de esir aldı ve konağı muhkem bir kale haline getirdi.

Olayın haber alınması üzerine Osman Paşa, evvela çevre köylerden asker celb edilmesini düşünmüş ise de; eşkıyanın sürekli hareket halinde olması, onu bu fikrinden caydırdı. Çünkü yardım kuvveti gelene kadar eşkıyanın kaçması muhtemeldi ve bu durumda eşkıyanın civar köylere saldırması kaçınılmaz bir son olacaktı. Zira askerden yoksun haldeki bu yerler savunmasız, saldırıya açık hale geleceklerdi. Bu da eşkıyanın işini kolaylaştırmaktan başka bir işe yaramayacaktı. Sadece Baba-yı Atik'ten beş yüz kadar asker getirilebildi. Bir taraftan asker toplamakla meşgul olan Osman Paşa, diğer taraftan Malkara'nın durumunu öğrenmek için bir adam yolladı. Bu adamın verdiği haberlere göre; Ahmed Haseki esir alınmış, eşkıya fidye olarak kırk bin kuruş istemekteydi. Bu fidyenin on beş bin kuruşunu ödemek isteyen ayan Ahmed'in kayınbiraderi de hem parasını kaybetmiş, hem de esir düşmekten kurtulamamıştı. Fidyenin kalan yirmi beş bin kuruşunun yanında elli vukıyye kahve, bolca nal ve beş at talebinde bulunan Kadri, "Göndermezlerse, kendileri bilir" şeklinde tehdit savurmayı da ihmal etmedi. Osman Paşa'nın çaresiz kaldığı bir anda Ayan Ahmed'in oğlu iki yüz kadar adamıyla Orşa'dan hareket ederek Kasım ayının ikisinde Malkara'ya ulaştı. Fakat Kadri'nin muhkem seddi, süvari olarak gelen yardım birliğinin kasaba merkezine girmesini engellemekteydi. Bunun üzerine atlarından inen ve piyade olarak hareket etmek zorunda kalan askerler, eşkıya ile şiddetli bir çatışmaya girdiler. Tam bu sırada Tekfurdağı ayanının gönderdiği üç yüz adam ile Osman Paşa'nın yüz kadar askeri kasabanın kurtarılmasını sağladı. Deli Kadri bu çatışmada

5 Kuleli, XVII. yüzyılda Edirne-Bergos arasında önemli bir menzil yeri idi (Altunan 2006: 75-99). 
iki yüz kadar adamını kaybederek kaçmak zorunda kaldı (BOA.HAT 57-2615-A; 57-2615-B; 542502-C; 54-2502-A).

Malkara çatışmasından sonra sayısı altı yüze kadar düşen eşkıyalara büyük katılımların olduğu söylentileri bölgede yayılmaya başladı. Özellikle iki binin üzerinde suhtenin Deli Kadri'nin maiyetine girdiği dedikoduları etrafta dolaşmaktaydı. Her ne kadar bunun, korku salmak için eşkıyanın bir taktiği olduğu anlaşılmışsa da söylentinin varlığı bile civar kasaba halklarının telaşa düşmelerine ve acil asker talebinde bulunmalarına yetmişti. ${ }^{6}$ Malkara çatışması payitahtta da büyük yankı buldu ve Deli Kadri ile Kara Feyzi'nin idamı için Selanik Mutasarrıfı Osman Paşa görevlendirildi (BOA.C.ZB 23-1105). Malkara ve İnecik tarafına doğru ilerleyen Osman Paşa'nın kuvvetleri önünde duramayacağını anlayan eşkıya, çareyi kaçmakta buldu. ${ }^{7}$ Malkara'dan kaçıp kuzeye, Edirne tarafına, doğru yönelen eşkıya yol üstünde Rusçuk tarafından gelen Rus ticaret kafilesine tesadüf etti. Eşkıya güruhu, Sava Dimitriyo, Todori Hristo ve Yorgi Mihailoviç adlı tüccarların üç bin Macar altınını gasp ettikleri gibi; aynı kafilede bulunan Anton adlı tüccarı da bin yedi yüz altını ile birlikte alıkoydu. Daha sonra doğuya, Pınarhisarı tarafına, yöneldiğinde bu defa Rumbeğli köyü civarında Avusturya tüccarlarına musallat oldular. Altı Avusturyalı tüccarı esir alan Deli Kadri ve Kara Feyzi her bir tüccar için onar kese akçe talep etmekteydiler. Kara Feyzi ve Deli Kadri'nin bu baskınlarının Rusya ve Avusturya ile olan barış ortamını bozmasından çekinen Sultan III. Selim, Osman Paşa'ya bu işin derhal halledilmesini emretti (BOA.HAT 216-11836; 216-11836-B). Fakat eşkıyayı yakalamak pek de kolay değildi. Çünkü Osman Paşa'nın da acı bir şekilde itiraf ettiği gibi eşkıya sürekli fikir değiştiren değişik bir tavır takınmaktaydı (BOA.HAT 57-2618-D). Gerçekten de eşkıya aniden geriye dönerek Malkara'nın hemen güney doğusundaki Ballı köyüne giderek buraya mevzilendi. Eşkıya peşindeki Osman Paşa için köyün düzlük arazisi büyük bir sorun teşkil etmekteydi. Çünkü düz bir arazinin etrafını çevirmek için yeterince asker ve mühimmatı yoktu. Hele askerlerin çoğunluğunun süvari olduğu bir birliğin yeterli mühimmat olsa da burayı kuşatması mümkün değildi (BOA.HAT 218-12031). Yine de Osman Paşa 2 Aralık Perşembe günü büyük bir çarpışmaya girmeye karar verdi. Fakat bu sefer de kışın ağır şartları bu mücadeleyi yarıda bıraktırdı. Harekât esnasında yağan aşırı yağmur, mevcut piyadenin ve top arabalarının ilerleyişini engellemekteydi. Yağmurun akabinde ortaya çıkan şiddetli rüzgâr üzerine Osman Paşa ve kurmayları attan bile inmeden meşveret edip, piyadeler kadar top ve silahların da daha fazla zarar görmemesi için ilerleyişin durdurulmasına karar verdiler ve biraz kuzeydeki Yörük köyüne sığındılar. ${ }^{8}$ Bu arada Tirsinikli'nin dört Bölükbaşı ile göndermiş olduğu iki yüz Arnavut askerin istihdamı sıkıntı oluşturdu. Tirsinikli'nin göndereceği askerlerin, mevcut askerlerle karışmaması zaten önceden tembihlenmişti. Şimdi de bunların sekbanlık yapmak istemeleri yeni bir sorunu doğurdu. Kimlikleri meçhul bu Arnavutların keyfiyetleri Mustafa Binbaşı'ya sorulmuş, hallerinden vukufları olmadığına binaen istihdam

Mesela eşkıyanın Hayrabolu'ya dönme ihtimali bulunduğunu düşünen kasaba halkı üç yüz asker talebinde bulunmuştu (BOA.HAT 57-2615-C; 59-2637).

7 Yanbolu ve Çirmen kazalarında okunan hükümlerde eşkıyayı yakalayıp, kellesini getirenlere o eşkıyanın malları vadedilmekteydi. (BOA.C.ZB 76-3778 Lef 1 ve 2).

8 Ballı köyüne yapılan bu harekât, Nizam-ı Cedit için de önemli bir sınav olmuştu. Bundan önce, eşkıya ile mücadele sekbanlar gibi başıbozuk askerler ile yapılmaktaydı ve halkı koruması gereken başıbozuklar, maalesef ahaliye zulüm ve teaddide bulunmaktaydılar. Bunun önüne geçme adına ilk defa bu kuşatma esnasında Nizam-ı Cedit askerleri kullanıldı. Nizam-ı Cedit askerleri kışlalarından çıktıkları andan itibaren sadece devlet erkânı değil, ahali hatta yabancı devlet temsilcileri bir büyük merak içerisinde idiler. "Acaba inzibat-1 hakîkî hâsıl oldu mu?" sorusunun cevabını merakla beklenilmekteydi. Yabancı devlet temsilcileri, Nizam-ı Cedit'i kışlalarından çıktıkları andan itibaren takip etmeleri için memurlar dahi görevlendirmişlerdir. Nihayetinde Ballı köyü kuşatmasında Nizam-1 Cedit askerleri rüştlerini ispat ettiler. Ahaliye zulmetmedikleri gibi, eşkıyayı da perişan bir hale düşürdüler (Ahmet Cevdet Paşa 1871: 359). 
edilmemeleri uygun görülmüştü. Fakat geri gönderilmeleri de büyük bir soruna neden olabilir, geri gönderildiklerinde kontrolden çıkarak başka taraflara geçebilirlerdi. Sultan III. Selim, Tirsinikli'nin askerlerinin Edirne'yi geçmesini şiddetle yasaklamıştı. Bu sebeple Arnavut askerler, civar köylerde arama tarama işlerinde kullanılmak üzere birliğe dâhil edildiler. ${ }^{9}$ Osman Paşa'nın kuşatmayı gerçekleştirememesi eşkıyanın yeniden firarına fırsat tanıdı. Aralarında birçok yaralının olduğu eşkıya, Ballı köyünden kaçıp bir gece sonra, Bergos'a tabi Ahmed Beyli'ye ulaştı (A.DVN.MHMd. 219/537). Civardan asker ve erzak temini ile uğraşan Osman Paşa, haberi alır almaz eşkıyanın peşine düşmek zorunda kaldı. Osman Paşa'nın isteği üzerine Kazanlık Serdarı Emin Ağa bir miktar askerle başbuğ tayin edilip, Osman Paşa'nın emrine verildi. ${ }^{10}$

\section{Kavaklı Çarpışması}

Deli Kadri ve Kara Feyzi, bulundukları yerden süratle tekrar güneye, Edirne tarafına yöneldiler. Zaten çok sayıda yaralı adamı bulunan eşkıyalar için kaçışlar oldukça zorlu geçmekteydi. Bu sebeple ağır yaralı olup, ümidini kestikleri eşkıyaları Meriç nehrine atmaktan çekinmediler. Edirne'ye bağlı Kavaklı köyüne ulaşan ve perişan halde olan eşkıya sayıca yarıya inmiş, üç dört yüz kadar kalmıştı. Ayrıca zahire ve barut sıkıntısı da çekmekteydiler. Osman Paşa Kavaklı'ya dört saat mesafede doğu tarafında üs kurarken, öncü birlik olarak Sarıgöllü Binbaşı'yı gönderdi. Kavaklı'ya bir saat mesafede siper alan bu birliğin yanında Tirsinikli de Balkan tarafını, yani batı yönünü, kapatınca eşkıya tam olarak çember altına alınmış oldu. Nizam-1 Cedit piyadeleri de Bergos tarafında hazır kıta bekletilmekteydi (BOA.HAT 56-2568). Osman Paşa, artık zafere çok yakın olduğu düşüncesinde idi ve Kavaklı'da sıkıştırılan eşkıyanın üzerine yürüdü. Paşa, askerlerin top atışları eşliğinde kırkar ellişerli gruplarla farklı yönlerden köye girerek eşkıyayı etkisiz hale getirebileceğini düşündügü bir plana odaklanmıştı. Top atışları ile eşkıyanın saklandığı yerden çıkarılması amaçlanmaktaydı; fakat istenilen sonuç elde edilememiş, eşkıya saklandığı yerden yaptığı tüfek atışları ile Osman Paşa'nın birliğine büyük kayıplar verdirmeye başlamıştı. Topların küçük olması ve eşkıyanın saklandığı mevcut binalara etki edecek kapasitede bulunmamaları paşanın planını suya düşürdü. Diğer taraftan gruplar halinde yapılan baskınlar; eşkıyaya kaçış için önemli bir avantaj sağlamaktaydı. Askerler gruplar halinde girince eşkıyanın bir kısmı ortaya çıkıp, peşine bu askerleri takarak hem kaçıyorlar hem de Osman Paşa'nın gücünü bölüyorlardı. Osman Paşa'nın bir çıkmazı da piyadelerin hareketinin bizzat Sultan Selim tarafından yasaklanmış olmasıydı. Eşkıya takibi sadece süvari ile yapılmak zorundaydı. Piyadeler Bergos'ta idi ve Sultan Selim bu askerlerin toplu halde Tekfurdağı'na dönmelerini emretmişti. Osman Paşa, kendisinin ifadesiyle Tekfurdağı'ndan izinsiz biçimde piyade askeri çıkartmaya cesaret edememişti. Sonrasında Tekfurdağı'ndan bin kadar piyade istemiş ve bunların gelişine izin verilmişse de bu iş için artık geç kalınmıştı. Osman Paşa, buna rağmen eski ayan Emin Ağa'nın konağındaki eşkıyalara büyük bir baskın yaparak çok sayıda eşkıyayı etkisiz hale getirmeyi başardı. Panik halindeki eşkıyalar Şahbazlı ve Subaşılı köylerine dağılmak zorunda kaldı. Bunun gibi kısmi bazı

\footnotetext{
$9 \mathrm{Bu}$ arada Deli Kadri'nin Malkara çatışmasında sol kolundan yaralandığı, kurşunun derisine işlediği ve merdivenden düşüp, yaralı kolunu kırdığını ve bu yaradan dolayı öldüğüne dair dedikodular etrafta dolaşsa da bunun doğru olmadığı anlaşılmıştı (BOA.HAT 72-3023).

10 Filibe Nazırı Kapıcı Hüseyin Beğ ise eşkıya takibinden yeni dönen askerlerin bitap halde olduğunu ancak bahar mevsiminde Osman Paşa'ya katılabileceğini söyledi (BOA.C.DH 109-5444; C.ZB 7-319; 9-446).
} 
başarılar elde edilmiş; eşkıyanın daha önce esir aldığı tüccar Anton ve yanındakiler kurtarılmıştı. ${ }^{11}$

Son çatışmadan sonra Deli Kadri ve Kara Feyzi'nin batıya Filibe ya da oradan Sofya tarafına doğru kaçma niyetinde oldukları anlaşıldı. Osman Paşa, takibatı sürdürmüşse de dağlık araziye kaçan eşkıya, izini kaybettirmeyi başardı. Daha sonra alınan istihbarata göre eşkıyalar, Zağra-ı Atik, Çırpan, Filibe, Tatar Pazarı kazalarının içinden geçerek Sofya'ya ulaşmıştı. Eşkıyanın bu kadar rahat bir şekilde hem de kaza merkezlerinin içinden geçmiş olmaları daha önce uyarılmış olmalarına rağmen (BOA.A.E.SSLM. III 171-10166; 199-11941; 30-1738; 339-19563; C.ZB 28-1365) bölge ayanlarının müsamahalarından başka bir şeyle açıklanamazdı. Bunu açıkça Sultan III. Selim de görmüş, yazdığı hatt-1 hümayunda ayanları bu tavırlarından dolayı eleştirmişti (BOA.HAT 214-11762; 77-137; C.DH. 52-2583 Lef 2). Sofya'dan daha kuzeye İzladi'ye doğru ilerleyen Deli Kadri ile Kara Feyzi, bölgenin dağlık yapısının verdiği imkânlarla saklanmayı başardılar (BOA.A.E.SSLM. III 372-21224; 372-21225). ${ }^{12}$

O dönemde Rumeli Valisi bulunan Yusuf Paşa kış ayları gelmeden eşkıya sorununa çözüm bulma adına çabalamaktaydı. Sofya'daki Alacahisar Sancağı Mutasarrıfı Şehsuvar Paşa ile bu konuyu müşahede etmişler ve her iki eşkıyanın da iskânının gerekliliği üzerine hemfikir olmuşlardı. Kara Feyzi'nin Filibe'ye iki saat uzaklıktaki Değirmendere'ye iskân edilmesi; Kadri'nin de yine Sofya'ya yerleşmesine müsaade edilmesi planlanmaktaydı. Her ne kadar zahire kıtlığından dolayı Sofya halkının bu eşkıyaları idare edemeyecek seviyede olduğu aşikâr olsa da bu iskânın gerçekleşmesi zaruri idi. Fakat Sofya mütesellimi Mehmed Beğ, kendisine yapılan bütün ihtarlara rağmen, Yusuf Paşa'nın tabiriyle "akl-ı kısırlığından dolayı" eşkıyanın Sofya'dan ayrılmasına izin verdi. Böylece ilk etapta eşkıyalıktan vazgeçeceğini ifade eden Kadri, kısa bir süre içerisinde bu sözünden vazgeçmiş ve yeniden yağmaya başlamıştı. Ayrıca Kara Feyzi de Filibe tarafına geçmiş ve bu ikili yeniden bir araya gelmişti (BOA.HAT 49-2348C).

\section{Deli Kadri'nin Çorlu ve Silivri'deki Eşkıyalıkları}

Deli Kadri ile Kara Feyzi Sofya'da birbirlerinden ayrıldılar. Daha doğrusu Feyzi, Filibe tarafına giderken, Kadri de Silivri ve Çorlu taraflarına ilerlemeye karar verdi (BOA.HAT 462264). Onun İstanbul'a bu kadar yakınlaşması tedirginliğe neden oldu ve derhal Levend Çiftliğinden süvari gönderilerek, başlarına Hassa silahşörlerinden ocak kethüdası Süleyman, başbuğ olarak atandı. Ayrıca Üsküdar ocaklarından ve sadrazam dairesinden tüfekçiler ile Anadolu mutasarrıfları kethüdaları ve civar kazaların ayanları maiyetleriyle beraber Selanik Mutasarrıfının emrine verildiler (BOA.A.E.SSLM. III 372-21224; 372-21225). Aslında bu askerler sadece eşkıyayı korkutma amaçlı bölgeye gönderilmişti. Çünkü bunların sahada kalamayacakları belirtilip, ulaştıkları kazalarda ikâmet ettirilmelerine dair emirler yazılmıştı. Üstelik asker için hazırlanması gereken zahire de ortalıkta yoktu (MŞH.ŞSC.d 7427/95-2). Bu arada Silivri'ye bağlı köyleri yağmalamaya başlayan Kadri yanındaki yedi sekiz yüz adamıla yine buradaki Balabanlı çiftliğine yerleşti. Niyeti Bergos tarafına gitmek olan Deli Kadri'yi bir takım sorunlar beklemekteydi. Yöre halkının kendisini istememesinin yanında Bergos tarafında yeni eşkıyalar türemeye başlamıştı. Her gün neredeyse yedi sekiz köy bu amansız eşkıyalarca

11 Tüccar Anton ve adamlarından alınan bilgilere göre; asi başlarından Kara Bayram ve Pazvandzade'nin çukadarı Süleyman öldürüldüğü gibi eşkıya içinde büyük bir karışıklık meydan gelmişti. Kara Feyzi ve Deli Kadri arkalarına bakmadan kaçmayı planlarken; çok sayıda yaralının buna itirazı üzerine iki eşkıya başı buna cesaret edememişlerdi (BOA.HAT 55-2535; 3358-A).

12 Bu sırada Deli Kadri'ye de özel bir mektupla eşkıyalıktan vazgeçmesinin tembih edilmesine karar verilir (BOA.HAT 136-5571) 
yağmalanmaktaydı (BOA.HAT 69-2923). Bu yağma faaliyetleri, İstanbul'un Bergos ve civarına asker sevk etmesine neden olmuştu. Bunun bir anlamı da Deli Kadri'nin askerlerle karşılaşma ve çarpışma riskinin artmasıydı. Nitekim Deli Kadri bir defasında köyleri yağmalamaya çıktığında Edirne'den dönen bu Osmanlı askerleri ile karşılaşmış ve Çorlu tarafına kaçmak zorunda kalmıştı (BOA.HAT 57-2616-B). Çorlu tarafında da eşkıyalığa devam eden Deli Kadri ve avaneleri bazı köylerdeki halkı kasabaya zorla göç ettirdikleri esnada Kırım Hanedanı mensubu Baht Girayhanzadeler'in kafilesi ile karşılaştı. Sahib Giray Han'ın Bergos yakınında bir çiftliği vardı (BOA.AE.SABH.I. 26-2001). Bu karşılaşma muhtemelen bu çiftlikten dönüldüğü sırada vuku bulmuştu. Kafiledeki malları yağmalayan eşkıyalar, Kırım Giray Sultanı da katletmişlerdi (Mütercim Ahmed Âsım Efendi, I, 2015: 108). Aynı gün Çorlu'dan çıkıp, Ereğli tarafına geçen Deli Kadri, Ereğli Kadısını da esir aldı. Önce Silivri'ye oradan da Bergos ve Çorlu'ya geçen eşkıyalar Kara Sekit çiftliğine yerleştiler. Diğer taraftan Çorlu-Tekfurdağ yolunu kapatan Deli Kadri, bu yolda gidiş-gelişleri imkânsız hale getirdi (BOA.HAT 56-2567).

Bu olay, İstanbul'un Kadri'ye olan bakış açısını değiştirdi. Deli Kadri ve avaneleri devlet erkânı tarafından "çalar çırpar makulesinden bir alay hırsız" olmaktan çıkarak, payitahtı tehdit edebilecek bir zorba olarak görülmeye başland1. ${ }^{13}$ Kendisine affedilme şartları iletilmiş olsa da "fitr-1 asliyyesinde merkûz olan hiyânet ve şekâvet muktezâsı üzre taraf-ı devlet-i aliyyeden erzân kılınan bunca müsaâde ve inâyetin şükrünü bilmeyerek şekâvetten vazgeçmemesi" üzerine Kapucubaşı Serezli İsmail, askeri bir çözüm olarak Kadri'yi ele geçirmekle görevlendirildi. ${ }^{14}$

Bu arada Çirmenli Mehmed Paşa'nın, saklandığı çiftliği öğrendiğini haber alan Kadri, burayı yakarak Bergos'a bağlı Sarılar köyüne kaçtı. Çorlu tarafında Kadri'ye yeni katılımlar oldu. Gümüşşene ve Pehlivan adlı bölükbaşılarına şimdi Zekir Arap ve Bayraktar Hasan da eklendi. Zekir Arap ve Bayraktar Hasan önceden Marmara Ereğlisi civarında faaliyette bulunmaktaydılar. Yüz elli kadar eşkıya ile Kadri'ye katıldılar. Baskın yaptıkları köy ahalisini "Arkadan külliyetli eşkıya geliyor" diyerek korkutan ve göçe zorlayan eşkıyanın dedikodusu Bergos'a kadar hızla yayıldı ve halkın bir kısmı Büyükçekmece tarafına doğru göç etmeye başladı. Yaşananlar üzerine Deli Kadri'nin bertaraf edilmesi için, başıbozuk askerlerin yeterli olmayacağı anlaşıldı. Artık tek çare; Nizam-ı Cedit askerinin kışlalarından çıkartılması idi (BOA.HAT 57-2616). Ayrıca Bergos'tan Küçük Çekmece'ye kadar olan bütün kazalara Deli Kadri'nin yakalanması için emirler gönderildi (BOA.A.E.SSLM. III 132-8026). Deli Kadri, Çorlu'dan önce güneye Tekfurdağı'na oradan da batıya İnecik'e ve akabinde Malkara'ya ulaştı (BOA.HAT 72-3026-A). Deli Kadri'nin Sofya'dan kaçışından sonra Avlonyalı Mehmed Paşa, Edirne Bostancıbaşısı ve Edirne Ayanı, Deli Kadri'nin yakalanıp, idam edilmesi için ayrıca görevlendirilmişlerdi (MŞH.ŞSC.d 7427/95-1). Çirmen mutasarrıfı Avlonyalı Mehmed Paşa, eşkıyayı takip ederek Serserli ${ }^{15}$ karyesinde yakaladı. Köyün sağ tarafını Mehmed Paşa, sol tarafını da süvari askeri başbuğu Osman Beğ tuttu. Edirne Bostancıbaşısı da köyün dere yatağı olan tarafında siper aldı. 28 Haziran Perşembe gecesi sabaha karşı yüz elli kadar eşkıya Osman

13 Sırp isyanının hız kazandığı bir dönemde Fransız diplomatlar, Osmanlı İmparatorluğunun Sırp asiler karşısında zayıf kalacağına dair iddialarında Deli Kadri'nin bu hadisesini delil olarak gösterirler: “Geçen sene Deli Kadri namında bir haydudun bin iki yüz kişiden ibaret olan maiyyeti efradıyla İstanbul kapılarına kadar bütün Rumeli'yi haraca kestiği ve Divan tarafından buna mukabele edilemeyerek şerrinden kurtulmak için Burgaz'a vali tayin edildiği düşünülecek olursa Sırpların Devlet-i Osmaniyye'nin kuvvetine karşı nasıl mukabele etmekte olduklarını anlamak kolaylaşır." (Driault 2013: 241).

14 Kendisine cephane-i amireden 30.000 deste (5 dirhemlik), 10.000 deste (2 dirhemlik) fişek, 303 sandık fişek, 600 kürek ile 500 kazma ve kabza tahsis edildi. (MŞH.ŞSC.d 7427/161-1).

سرسرلى 15 
Beğ'in tarafına hücum ederek muhasarayı yarmaya çalışmışsa da başaramamıştı. Bu arada iki Enderun ağasına isabet eden kurşunlar incelendiklerinde, dökme oldukları görülmüş ve eşkıyanın mühimmatının tükenmek üzere olduğu anlaşılmıştı. Diğer taraftan köyden kaçan bir çoban, Deli Kadri ile Zekir Arab'ın birbirlerini suçlayarak kavga ettiklerini belirtir. Kuşatmayı haber alan Sultan Selim, muhasaranın şiddetinin arttırılmasını emretmişti (BOA.HAT 49-2324). $\mathrm{Bu}$ üç komutan, Kadri'yi ormanlık bir alanda sıkıştırmayı başarmışlarsa da aralarındaki koordinasyon eksikliği Kadri'nin kuşatmadan kolayca kurtulmasını sağlamıştı (Journal des débats et des décrets, 25 Nisan 1805).

Deli Kadri ve avaneleri yine kaçmayı başararak kuzeye Uzun Köprü'ye bağlı Yayalar köyüne ulaştı. Burada Kara Feyzi ile yeniden bir araya geldiler ve her zaman olduğu gibi civar köyleri yağmalamaya başladılar. Eşkıyanın köyleri ısrarla ve sürekli yağmalaması sadece iaşe açısından değil; aynı zamanda kurşun ve barut gibi mühimmatların da karşılanması açısından hayati bir öneme sahipti. ${ }^{16}$ Bunun üzerine Rumeli Valisi İbrahim Paşa, Sofya'da mukim Süleyman Paşa'yı eşkıya takibine gönderdiği gibi Nizam-1 Cedit piyadeleri de Silivri'den hareket etmekteydi. Süvari birlikleri de Çorlu'da konuşlanmış; Malkara ve Haseki-yi Kara ayanları da altı yedi yüz kadar süvari ile Malkara'da toplanmışlarsa da Edirne ayanının ilamında itiraf ettiği gibi Kadri ve avanesi sürekli yer değiştirdiğinden onu yakalamak neredeyse imkânsızdı (BOA.HAT 69-2921-A; 49-2347; 57-2590; 53-2478). Deli Kadri'nin bu esnada bin kadar adamı var idi. Lakin bunların sadece yarısı muharip durumda idi ve genelde süvari idiler. Aslında onun asıl amacı; doğduğu yer olan Bergos'u ele geçirmekti. Fakat adamlarının yetersiz olduğunu kendisi de bilmekte, bu sebeple Bergos'u istilaya cesaret edememekteydi. Ayrıca kendisine katılımların; özellikle de savaşacak özelliklere sahip olanların azlığı da planlarını uygulamasını engelliyordu. Kara Feyzi, 1srarla birlikte hareket etmeyi ona teklif etse de Deli Kadri için Bergos'u ele geçirmek ve oranın hâkimi olmak her şeyden önce gelmekteydi ve Kara Feyzi'den ayrılarak yeniden Bergos tarafına yöneldi. Fakat kaza merkezine yakın bir mevkide Süleyman Kethüda komutasındaki süvari, piyade ve topçu birliği ile karşı karşıya kalınca tekrar kaçmak zorunda kaldı. Aslında aralarında sadece Ergene nehri var idi ve askerler eşkıyayı takibe başlamışlardı. Fakat uzun süreli bir takip gerçekleşemedi. Çünkü birliğin cephanesi Tekfurdağı'nda idi. Yani en az eşkıya kadar, Osmanlı askerleri için de ani bir karşılaşma olmuştu ve hazırlıksız olmaları, mutlak bir zafere mani olmuştu. Takip esnasında birkaç eşkıyayı öldürmekten başka bir şey yapamadılar. Eşkıya Tunca Nehrini aşarak Hassa Köy taraflarına kaçtı ve bir süre kendisinden haber alınamadı. Asker ise Hayrabolu taraflarında onu arar iken, Deli Kadri birden Silivri taraflarında göründü. Bogados (Selimpaşa) karyesinde olduğunun haber alınması üzerine derhal Üsküdar'daki kışladan beş yüz Nizam-1 Cedit askeri bölgeye gönderildi. Haberi alan Sultan III. Selim de "Şu hınzırların nerde olub ne taraflara îsâl- $i$ hasâr iyledikleri şimdi arz oluna, niçün haber alınmaz Bogados şurada" diyerek askerlerine öfkelenmekteydi. Padişah haklıydı; çünkü Deli Kadri Silivri civarında yoğun bir eşkıyalık faaliyetine girişmişti (BOA.HAT 84-3462; 57-2591; 57-2599; 55-2552; 56-2565).

\section{Serezli İsmail'in Misyonu}

Deli Kadri'nin bir türlü yakalanamaması ve eşkıyalığının payitahtı tehdit edecek kadar tehlikeli bir boyuta ulaşması onun yeniden iskân ettirilmesi fikrini doğurdu. Hayrabolu ya da Pınarhisarı kazalarından birine Kadri'nin iskânı mevzubahis oldu. Lakin yöre halkının eşkıyanın iskânına rızası kati surette yoktu. Yöre halkı o kadar şiddetli şekilde karşı çıkmıştı ki bir çatışma yaşanma riski iskânın gerçekleşmesine müsaade etmedi. Bunun üzerine

16 Deli Kadri'nin mühimmatı temin ettiği yerlerden birisi de Kırcali Dağları idi (BOA.HAT 84-3462). Kırcali Dağları, on sekizinci yüzyılın ortalarından itibaren eşkıyalara yataklık eden önemli bir bölgeydi (Yıldız 2017: 51). 
Üsküdar'daki Nizam-ı Cedit askerleri hazırlık için talimlerinin yapılacağı Levent Çiftliğine gönderildiler. Kaza merkezlerindeki halkın eşkıyayı istememesi üzerine geçici olarak eşkıyanın köylerde iskânının daha uygun olacağı düşünüldü. İskânın gerçekleşmesi halinde eşkıyanın nasıl dağıtılacağı konusu henüz aydınlığa kavuşturulamamıştı. Genel kanı; eşkıyaya birkaç aylık ulufe verilerek, Rumeli Valisi maiyetine verilmesi veya bunları birbirlerinden ayırma adına memleketlerine gönderilmeleri yönünde idi (BOA.HAT 56-2563).

Deli Kadri'yi eşkıyalıktan vazgeçirme çabaları üzerinde durulması boşuna değildi. 1805 yılının yaz mevsiminde Kadri büyük infiale neden olacak bir olaya girişti. Çorlu tarafından hareket eden Deli Kadri ve avaneleri Tekfurdağı'na geçip, donanmaya kurşun sıkıp, gemilerin camlarını kırmışlardı. Eşkıya takibine görevli olan Serezli İsmail, Kadri'nin peşine askerle düşülmesi için takrir yazmışsa da merkezden ona verilen cevap devletin bu konudaki tutumunu göstermekteydi. Ona "devletin bunu hazmettiği" ifade edilmiş ve Kadri'nin asilerini dağıtarak eşkıyalıktan vazgeçmesini sağlaması emredilmişti (BOA.HAT 75-3101). Yani Serezli İsmail sadece iskân için yetkiliydi. Aldığı emir ile Gümülcine'den Tekfurdağı'na hareket eden Serezli İsmail'in temel görevi Kadri'yi ürkütmeden emri altındaki eşkıyayı dağıtmak idi. Bunu yaparken de bu eşkıyaları ya isyan halinde olan Sırplar üzerine gönderecek ya da memleketlerine dönmelerini sağlayacaktı (BOA.HAT 48-2312; 59-2660-C). Serezli İsmail daha yolda iken, yanında bulunan Kır Serdarı Mustafa Bey'i Kadri'yi bulup, iskânı hususunda kendisini bilgilendirmesini istedi. Deli Kadri ile yapılan bu ilk görüşmede onun Hayrabolu ve Pınarhisarı'nı hatta Bergos'u ele geçirmeden ve oraların hâkimi olmadan bu işten vazgeçmeyeceği anlaşılmıştı. Deli Kadri, Pınarhisarı ve Hayrabolu'nun kendisine verilmesi durumunda eşkıyasından bin tanesini Sırpların üzerine göndereceği taahhüdünde bulundu. Serezli İsmail, Kadri'nin bu yaklaşımından onun açgözlü olduğunu ve buralar ona verilse dahi bununla yetinmeyip, yağmaya ve çapulculuğa devam edeceğini düşünmekteydi. Bu arada Kadri, verdiği sözü tutacağının bir nişanesi olarak adamlarını bu iki kasabadan çekti. Hatta halk ve ayan bir araya gelerek teşekkürlerini sundukları gibi Kadri'nin bölgeye gelmesi ile huzurun kalmayacağını ve ondan kendilerini kurtarmalarını adeta yalvararak talep etmişlerdi. Serezli İsmail bu işin suhuletle çözülmesinin mümkün olmadığı kanaatindeydi ve askeri tedbirlerin muhakkak alınmasını İstanbul'a bildirdi (BOA.HAT 59-2660-C).

Serezli İsmail Tekfurdağı'na vardıktan sonra bir kısım tedbirlerin gerekli olduğuna işaret eden bir tahrirat kaleme aldı. Tahrirat tamamen askeri çözüme odaklı olup, metinde askeri bir operasyonun zorunluluğu üzerinde ısrar edilmekteydi. Ona göre alınması gereken tedbirler şu şekildeydi:

1) Zahire kıtlığı ve halkın perişanlığı söz konusudur. Bu yüzden zahirenin kazalardan toplanması için bir nüzul emininin tayini

2) Askerlerin korunmasına dair bir ferman ısdar edilmeli ve askerin sevkiyatı için bir başbuğ tayini

3) Deli Kadri'nin iki bin civarında eşkıyası mevcut olup, onu muhasara edebilme adına iki bin Nizam-1 Cedit piyadesi ve iki bin Nizam-1 Cedit süvarisi ile üçer beşer kıyyelik on top, dört humbara, bol miktarda fişek hamulesi ve mükemmel bir cephane tertibi

4) Muhasara için gerekli olan kürek, kazma ve metris imalı için fazlaca amele ve hayvan gereklidir. Bunların başbuğ maiyetinde olması

5) Eğer eşkıya ardına düşmek gerekirse civar yerleşim birimlerinin ayanlarına ve kadılarına tayin edilen başbuğun emrine girmeleri gerektiğine dair bir emirnamenin yazılması

6) Civar köy ahalilerinin zahire ve eşyalarını kasaba ve muhkem yerlere götürmelerine 
dair Edirne, Filibe ve Sofya havalilerine hükümler yazılması

7) Eşkıyaya silah satan ya da yardım eden herhangi bir kaza olursa oranın ayan ve zabitanın tutuklanarak gerekli cezalara çarptırılacağına dair bir fermanın yayımlanması

8) Eşkıyanın Balkanların öte tarafına geçmesi durumunda askerlerin onları takip etmeleri gerektiğine dair bir emirnamenin yazılması (BOA.HAT 59-2660-A).

Serezli İsmail, bu tedbirler üzerinde dururken, Kadri ile iletişim kurmayı başarmış ve Sultan Selim'in eşkıyalığı bırakıp, devletine sadık bir kul olarak Bergos'ta ikâmet etmesi yönündeki emrini ona iletmişti. Deli Kadri, kendisine gönderilen mektuba cevabında, eğer padişah arzu ederse Pınarhisarı ve Hayrabolu'daki eşkıyalarından bin tanesini asker olarak yazıp, Rumeli valisinin hizmetine göndereceği yönündeki taahhüdünü yenileyip, ahalinin kendisinden emin olmaması durumunda kendi adamlarından birkaçını rehin olarak verebileceğini ve bu iki kazada ikâmet etmek istediğini israrla beyan etti. Fakat Serezli İsmail, Kadri'nin eşkıyasını dağıtarak ikâmet edebileceği tek yerin Bergos olduğunu, diğer şıkkın yani Pınarhisarı ve Hayrabolu'da yerleşme isteğinin yöre halkına vereceği zarar riski sebebiyle mümkün olmadığını belirtti. Ayrıca Bergos'ta da ancak üç yüz adam bulundurabileceği ifade edildi. Bu cevaba tatmin olmayan Kadri, isteklerini şifahen tekrarlamak için bizzat Serezli İsmail ile bir araya gelmeye karar verdi (BOA.HAT 59-2660-B).

Deli Kadri ile bir araya gelecek olan Serezli İsmail, onu tanımadığını ama Kadri gibilerin "mütelevvin" ve "müvesvis" yani kararsız, dönek ve işkilli olduklarını bildiğinden; görevinin ayrıntılarına değinmeden önce onu tanıma adına dostluk içeren bir mektubu yazıp, gizlice bizzat kendi eliyle Kadri'ye verdi. Kendi ifadesiyle Serezli İsmail, Deli Kadri'nin nabzını ve mizacını yoklamayı amaçlıyordu. Deli Kadri'ye tıpkı bir kardeş gibi yakınlaşarak olarak onun bilinçaltında yatan asıl düşüncesini öğrenmeye çalışan Serezli İsmail, Deli Kadri ile yaptığı görüşmede; psikolojik bir tahlile giderek; daha önce ifade edilenin tersine Kadri'nin emri altındaki eşkıya ile tam bir ittifak halinde olduğunu anlamıştı. Hayrabolu ve Pınarhisarı zapt edip, emniyet altına almadıkça da bir askerini dahi bırakmayacağından emindi. İsmail ilk anda Kadri'nin bununla yetinmeyip, Bergos'ta ısrar edeceğini de düşünmekteydi. Bu yüzden, askeri tedbir kabilinden olmak üzere Balkanların öte tarafına yetkili bir memur tayini ile takviye asker gönderilmesini özellikle istirham eylemişti ki onun bu tahmini doğru çıacak ve Kadri Bergos'tan vazgeçmeyecekti. Buna rağmen, onun bu talebi reddedildi ve ne isteniyorsa onu yerine getirmesi, yani evvela Kadri'yi ikna etmesi ve ardından eğer Kadri'yi kandırabilirse, askeri bir süre daha bölgede tutması emredildi (BOA.HAT 59-2660). Serezli İsmail, Deli Kadri ile yaptığı görüşmeden sonra askeri operasyon fikrinden tamamen vazgeçti. Onun peşine asker takıp, onunla askeri çatışmalara girmenin bu işi çözemeyeceği ve Kadri'nin bu şekilde eşkıyalıktan dönmeyeceğini kesin bir şekilde anlamıştı. Serezli İsmail'e göre yapılması gerekenler; Hayrabolu'ya "iyi bir kadı"nın tayini ve eşkıyanın kendisi ile beraber belirleyecekleri bir köye yerleştirilmeleri idi. Halk ile Kadri birbirlerini benimseyene kadar da ne asker ne de başka asilerin bu köye girişine izin verilmeyecekti. Eğer olur da kendisinin bu teklifi kabul edilmez de Kadri'nin üzerine varılmak istenirse zahire yokluğunun unutulmaması gerektiğini hatırlatarak derhal bir nüzul emini tayini ile bir başbuğun asker üzerine verilmesini talep eder. Ayrıca bölge ayanlarının da aciz karakterli olduğunu belirtir. Onun bu tahriratı üzerine Sultan Selim Serezli İsmail'in sözlerinin "gayet yollu" olduğunu belirtip, devletin içine düşmüş olduğu zafiyeti itiraf ederek hayıflanır: "Vâk'â 'askere zahire lâzım, bak şu civâr-ı saltanâtın hâline. Hasbinallah ve nimel-vekil bu husûslara îtimâm ve dikkat olunsun." Serezli İsmail'in talebi doğrultusunda bir nüzul emini tayin edilir. Ayrıca eşkıyanın dağıtılması için son bir şık üzerinde durulur. Kadri'nin bölükbaşlarından olan Mahmut, Sırplar üzerine giden Alacahisar 
Sancağı Mutasarrıfı Şehsuvar Paşa'nın maiyetine gitmeye razı edilecektir. İlerleyen dönemde Deli Kadri'nin de Sırplar üzerine gönderilmesine çalışılacaktır (BOA.HAT 48-2312).

Nihayet "Tahsîl-i rızâ-yı âliye itinâ taahhüdâtıyla" iskânı kabul edilen Kadri etrafına bin beş yüz kadar adam toplamıştı. "Ben buradan rizâ yararı ile bir çiftlik alıp, zahîre anbarı dahi tanzîm ve kendi halimde ikâmet ederim; lakin bu sûrete bir nizâm verinceye kadar fukâraya zarûrî bâr olurum." diyen Kadri gerçekten haklıydı. Şimdi en büyük sorun bu eşkıyanın iaşesinin karşılanması idi. Civar köylerden bir defaya mahsus olmak üzere bir miktar tayinat verilmişse de Sultan III. Selim, buna pek içerlemişti. Padişah, derhal eşkıyanın dağıtılmasını hatta Mısır'a, Mehmed Ali Paşa'ya, gönderilmelerinin bir yolunun olup olmadığını sadrazama danışmıştı (BOA.HAT 512385; 58-2627; 58-2627-D). III. Selim, Deli Kadri'nin askerinin dağıtılmasında ısrarcı idi; fakat Deli Kadri askerlerine söz geçirmekte zorlanıyordu. Bunun bilinçli bir hareket olduğu açıtı; fakat yine de Deli Kadri'nin adamlarının talep ettikleri şekilde Hayrabolu taraflarına yerleştirilmelerine izin verildi. Nasıl olsa bu asilerin ilerde bir şekilde dağıtılabileceği kanaati hâsıl oldu ve ayrıca kısa süreliğine de olsa bu iskân, onları eşkıyalık faaliyetlerinden alıkoyabilecekti (BOA.HAT 57-2606). Deli Kadri'ye verilen üç aylık tayinat ile birlikte kendisine bağlı eşkıya takımını dağıtıp, çatışmaları bitireceğine dair bir senet alınmasına karar verildi. Kadri'nin eşkıya takımının da halkın bütün itirazlarına rağmen cebren de olsa Hayrabolu ve Pınarhisarı taraflarına iskânlarının gerçekleştirilmesi için kesin karar alındı. Ayrıca diğer bölge ayanlarına da Kadri'ye ilişmemeleri yönünde tembihatta bulunuldu (BOA.HAT 48-2310; 482310-A; BOA.A.E.SSLM. III 401-23110). Hayrabolu ve Pınarhisarı ahalilerinin iki bölükbaşının gelişine itiraz edecekleri ve halk ile bölükbaşları arasında bir çatışmanın vuku bulacağı aşikârdı. Böyle bir durumda; civar yerleşim yerlerinin ayanları doğrudan bu işin kontrolünden sorumlu olacaklardı. Yine Adapazarı tarafında hazır kıta süvariler ile ocaktan gelecek olan süvariler derhal olaya müdahale edeceklerdi (BOA.HAT 255-14502).

Devlet erkânı iskân üzerine çalışırken Deli Kadri, kazma kürek alma bahanesiyle Hayrabolu taraflarına geçti. Ne yapacağı tam olarak bilinmeyen Kadri'nin isyan etme potansiyeli dikkate alınarak, mevcut beş yüz süvarinin yanına bin beş yüzü daha yardıma çă̆rıldı. Serezli İsmail hemen Kadri'nin peşine düştü. Eğer Kadri'nin eşkıyalığa devamda kararlı olduğu anlaşılırsa Tirsiniklizade'ye de haber verilecekti. Gerçekten de tam da düşünülen gibi oldu (BOA.HAT 255-14502). Kadri iskânı kabul etmiş olsa da hâlâ eşkıyalığa devam üzere idi. Hayrabolu'dan hareketle Tekfurdağı'na geçen Kadri, Yağcılık köyü civarında sıkıştırılmış, beş altı saat süren çatışmadan sonra üç yüz elli kadar eşkıya yardıma gelince, birlik geri çekilmek zorunda kalmıştı. Gece yarısı kuşatmayı yaran Kadri yine kaçarak, Hayrabolu ve İnecik taraflarında yağmaya devam etti (BOA.HAT 78-3257; 79-3268; BOA.C.DH 27-1332 Lef 3). Yaz mevsiminin sonlarına doğru Deli Kadri nihayet kendisine sunulan teklife kesin biçimde "evet" dedi. Ama yine bir şartı vardı: Bergos'ta bulunan iskân görevlileri kasabayı derhal terk edeceklerdi. Nihayet Deli Kadri Pınarhisarı ve Hayrabolu sevdasından vazgeçerek iki yüz kadar adamıla Bergos'ta ikâmete razı oldu ve birçok yere Deli Kadri'nin affedildiğine dair emirler gönderildi (BOA.HAT 73-3038; 104-4096; BOA.C.ZB 11-530; A.DVN.MHMd. 223/1 ve 2).

\section{Bergos Ayanı Abdülkadir}

Kadri Bergos'a yerleştikten sonra en önemli konu, ilk etapta kendisinin ve etrafındakilerin iaşesinin sağlanması idi. Çevre kazalardan iaşe gelmeye başlamışsa da oldukça ağır işleyen bir süreç yaşanmaktaydı. Ayrıca Kadri, bazı eşkıyalarına söz geçirememiş ve ondan ayrılan altı yedi yüz kadar eşkıya Çırpan taraflarında yağmaya başlamışı (BOA.HAT 150-6316-G). Gerçekten de bir süre sonra Hayrabolu halkı bu bölükbaşlarının ayanlığa seçilmesinden sonra 
isyan edip, olay çıkarmışlardı (BOA.HAT 78-3231). Eşkıya ile olan mücadeleye dâhil olması ile Kapucubaşı unvanını da alan Kadri istediği şeyleri elde etmiş olsa da verdiği sözü tutmamakta 1srarciydı (BOA.C.AS 1222-54853).

Bergos'a yerleşen Deli Kadri'ye artık eşkıyabaşı, rezil, serseri, asi gibi ağır hakaretlerle değil de Bergos Ayanı olarak hitap edilecekti. Hatta ayanlığa terfi ettikten sonra kaleme alınan belgelerde adının tam olarak Abdülkadir olduğu da anlaşılmaktadır. Yani eşkıyalığı döneminde Kadri'nin adı bile tam olarak belgelere yazılmamaktaydı ki bunun devletin diplomatik bir hakareti olduğu düşünülebilir (BOA.HAT 58-3630-A). Bergos ayanı Abdülkadir için artık yeni bir dönem başlamıştı. Kendisinin ilk ve en önemli görevi Bergos'ta türeyen eşkıyalarla mücadele etmekti. Bergoslu Molla Haseki'nin oğlu, Odacioğlu ve Belvelioğlu olarak bilinen eşkıyalar tarafından katledilmişti (A.DVN.MHMd. 223/190). Silistre Valisi Yusuf Paşa, bu eşkıyaları bertaraf etmekle görevlendirilmiş, Abdülkadir de paşanın emrine girmişti (BOA.C.ZB 50-2499; A.DVN.MHMd. 223/251). Daha önceden alınan karar gereği Bergos ayanı Abdülkadir Sırp isyanını bastırmak için görevlendirilen Alacahisar Sancağı mutasarrıfı Şehsuvar Paşa maiyetine verildi. Böylece kendisi Niş muhafazasına memur edilmiş oldu. Daha Bergos'a yerleşmeden Niş'e gönderilerek hem oranın askersiz bırakılmaması sağlanacaktı hem de böyle karışık bir zamanda Bergos'taki bir karışıklık önlenmiş olunacaktı. Bergos ayanı Kadri, bölükbaşılarından Vireli Mehmed kumandasındaki bin askerini Şehsuvar Paşa'ya gönderecek (A.DVN.MHMd. 223/251) kendisi de Şehsuvar Paşa'nın maiyetinde olacaktı (BOA.C.AS 271240; 104-4096; 133-5012). Sırplar üzerine yapılacak olan sefer için Kadri ve maiyetine üç aylık doksan bin kuruş verildi. Fakat Kadri, bu parayı aldıktan sonra ne Şehsuvar Paşa'ya katıldı ne de sefere iştirak etti. Kadri ortadan kaybolmuştu. Rumeli Valiliğine yeni atanan ve İskenderiye'den gelen Arnavut İbrahim Paşa, Kadri'nin peşine düşmek için izin istemiş ve ona Kadri'yi gördüğü yerde yok etmesi emredilmişti (BOA.HAT 150-6333; MŞH.ŞSC.d 7427/172-2). Deli Kadri'nin nerede olduğu kısa bir süre içerisinde ortaya çıtı. Sofya civarında Rumeli ordusuna ait zahireyi taşıyan arabaları gasp edip, arabacıları da öldürmüştü (BOA.HAT 1506330). Bu olaydan sonra Kadri'nin öldürülme korkusuyla orduya katılmayıp, telaş içerisinde yağma yaptığını ifade etmesi ve iki sergerdesi ile bin kadar adamını Şehsuvar Paşa'ya göndermesi üzerine savaş ortamının vermiş olduğu havanın da etkisiyle Kadri affedildi. Kendisi birkaç yüz adamıyla Köstendil'e tabi Payança nahiyesine yerleşme talebinde bulundu. Halka zulmetmeme teminatıyla bu talebi kabul görüldüğü gibi sergerdelerine hilat, kendisine de samur kürk giydirildi (BOA.HAT 120-4860). Bir süre sonra Bergos tarafına geçen Deli Kadri, yine rahat durmadı ve ulufe alamadıkları bahanesiyle civar kasabalara zarar vermeye başladı (BOA.C.AS 1053-46287). Rusya ile olan savaş esnasında Sırpların yanında asi dağlı eşkıyaları da Rusya'yla ittifak yapabilmekteydiler. Kara Feyzi ile yeniden buluşan Deli Kadri'nin üzerine Bosna Beylerbeyi İdris Paşa gönderildi ve Kadri'nin Sırp ve Ruslarla muhtemel bir ortaklığ engellendi (Jorga 1914: 136; aynı mlf. 2005: 145) ve nihayet 1807 yılının Kasım ayında Rumeli Valisi Hurşit Paşa, vatanına ihanet eden Deli Kadri ve avanesinin başlarını keserek İstanbul'a gönderdi (BOA.C.DH 137-6814). ${ }^{17}$

\section{Sonuç}

Yaklaşık on yıl boyunca Doğu Rumeli ve civarında eşkıyalık yapan Deli Kadri, bu mücadelenin neticesinde Bergos ayanı olarak kendisini kabul ettirmeyi başarmıştı. Fakat siyasal hedeflerden uzak yaşamının asıl biçimi olan eşkıyalık onun sonunu hazırladı. Osmanlı İmparatorluğu onun gibi bir eşkıyayı tam üç defa affetmişti; ta ki eşkıyalığının düşmanla

17 Câbî Ömer Efendi, eserinde Deli Kadri'nin Silivri, Çorlu ve Baba-yı Atik taraflarında vuku bulan ve ordu mühimmatının yağmalandığı olaya karışıp, idam olunduğu bilgisini verir (Câbî Ömer Efendi, I, 2003: 63-64). 
işbirliği içerisine girme ihtimaline kadar. Devlete isyan halindeki Sırplar ile giriştiği dirsek teması bile Kadri'nin idam edilmesine yeterli bir sebep olarak görülmüştü. İmparatorluğun Deli Kadri ile özellikle son beş yıllık mücadelesi, dönemin eşkıya-devlet ilişkisinin bir portresi olarak görülebilir. Zira merkezi otoritenin sıradan bir dağlı eşkıyası karşısında içinden çıkılamaz bir duruma düşmesi, sadece Deli Kadri'ye özgü bir niteliği haiz değildi. Deli Kadri ile olan mücadele bazı özel şartları içerse de devlet-eşkıya ilişkisinde imparatorluğun genel reflekslerini ortaya koyma açısından önemli görünmektedir. Dolayısıyla burada bu mücadelenin uzun süre başarısızlıkla devam etmesinde Deli Kadri'nin kendine özgü eşkıyalığı kadar imparatorluğun eşkıyaya yönelik sorunlu siyaseti de etkili olmuştur. Deli Kadri açısından bakıldığında dağlı eşkıyalarının Balkanları kasıp kavurduğu bir dönemde onun bazen cebren, bazen de kendi gücünü abartan dedikodular yayarak halkı göçe zorlayıp, sosyal ve ekonomik düzeni alt üst etmiş olduğunu ve ortaya çıkan kargaşa ortamını kendi lehine kullanmasını bildiğini söylemek gerekir. Deli Kadri, hızlı manevralarına engel olabileceğini düşündüğü yaralı askerlerini gözünü kırpmadan feda edebilmekteydi, dolayısıyla onun Osmanlı askerleri karşısındaki en önemli avantajlarından biri hızlı hareket edebilme kabiliyeti idi. Deli Kadri, bölgeyi gayet iyi tanımakta, askeri strateji yönünden de düşünülenden daha bilgili görünmekteydi. Saklandığ 1 ve tahkim ettiği yerleri bilinçli şekilde tercih ettiği söylenebilir. Ya Osmanlı süvarilerinin giremeyeceği şekilde çok dağlık ya da girdiklerinde açık hedef haline gelecekleri oldukça düz ve geniş arazileri tercih etmekteydi. Nitekim her iki durumda da kuşatılma riski son derece azdi.

Osmanlı komutanları, eşkıyanın mizacını bir türlü anlayamadıklarından, Deli Kadri'nin ne zaman ve nasıl hareket edeceğini bilememişlerdi. Bu açıklarını kapatma adına istihbarat ağını kullanmışlarsa da belgelerde sıkça ifade edildiği üzere bu istihbarattan alınan bilgiler genelde yanlış çıkmaktaydı. Osmanlı askerleri genelde başıbozuk askerlerden oluşmaktaydı. İmparatorluk açısından bakıldığında dağlı eşkıyaları ile mücadelede yaşanan önemli sorunlardan birisi ordunun sevk ve idaresi idi. Osmanlı ordusunun bir diğer sorunu da piyadesüvari dengesinin doğru bir şekilde sağlanamamasıydı. Eşkıya takibinin süratli bir şekilde yapılması için atlı birliklerin yani süvarilerin kullanılması şarttı. Fakat eşkıyalar takibat esnasında değil, sığındıkları köy veya kasabalarda sıkıştırılabilmekteydi. Kuşatma için eşkıyanın bulunduğu mevziye giriş ise ancak piyade askerleri ile mümkün olmaktaydı. Oysa piyadenin hareketi bizzat Sultan III. Selim'in iznine bağlı idi. Dolayısıyla eşkıya herhangi bir yerde sıkıştırıldığında muavenet kuvveti niteliğindeki piyadenin gelişi uzun sürmekte, bu da eşkıyanın elden kaçmasını kolaylaştırmaktaydı. Öte yandan Tirsinikli örneğinde olduğu gibi, civar bölgelerden gönderilen piyadelerin güven vermeyişi üzerine bunların pasif görevlerde istihdam edilmeleri ordunun gücünü azaltmaktaydı. Ayrıca asker sayısını arttırmak; uzun süren eşkıya takibinde mühimmat ve iaşe sorununu da beraberinde getirmekteydi. Yine belgelerden anlaşıldığına göre; eşkıya takibi ile görevlendirilen kurmaylar, kritik anlarda kendi salahiyetleriyle karar vermeye cesaret edememekteydiler. Bunun yanında komutanların Kavaklı kuşatmasında olduğu gibi yanlış taktiklerde ısrar etmeleri eşkıyanın firarına neden olan diğer bir faktördü. İstenilen yardımların zamanında ulaşmamasının yanında eşkıya takibinde önemli bir misyona sahip olan bölge ayanlarının ordu ile olan koordinasyon eksiklikleri de kuşatmaların genelde başarısızlıkla neticelenmesine sebebiyet vermekteydi. Bölge ayanları için eşkıya ile mücadele etmek her ne kadar merkezle olan ilişkilerinde onlara fayda sağlıyor olsa da kendi aralarındaki mücadelelerde, bu politikanın tam tersine eşkıyalara sahip çıkıp, onları kollamakta idiler. Hatta Sultan III. Selim bile onlara güvenemediğini açıkça ifade etmek zorunda kalmıştı. Eşkıyalarla olan mücadelede uygulanan iskân politikası pratikte 
istenilen sonucu vermemekteydi. Çünkü uygulamada eşkıyalara fazlaca taviz verilmekte ve dolayısıyla onlara bir o kadar da güven duyulmaktaydı. Bu durum, eşkıyanın iskâna tabi tutulduğu bölgelerde denetimi zayıflatmaktaydı ve eşkıya ile olan mücadele daha girift bir hale girerek, başarı elde edilmesini zorlaştırıyordu.

\section{Summary}

The reign of Sultan Selim the third (1789-1807) was a period when the Balkan bandits, also known as the mountain bandits had oppressed the region. In this period of great authority gap, it was seen that increasingly powerful influence of the ayans (landed proprietor in Ottoman Empire) started to erect their influence instead of the Ottoman state. But the ayans chose to prioritize their interests instead of using their authority on behalf of the empire. Therefore, it was not possible to prevent the banditry for the local forces too. During this period, Bergos, which was so to speak like the cellar of Istanbul, was an important activity area for bandits. In particular, the road between Bergos and Kırkkilise was an area known as "bandit hideout". In this region where the activities of bandits are intensive, Deli Kadri came in sight during the last period of the reign of Sultan Selim III and caused a lot of troubles to the government. He was able to sacrifice his own men, never thought of going backwards, took each day as it comes, saw looting as a means of living; but what made Deli Kadri, who in fact had such a cowardly personality, different from the other bandits who also took part in the power struggle with the government is that banditry was a lifestyle for him. This work, which is based on the Prime Minister's Ottoman Archives, aims to show how a bandit prepossess the central authority and try to evaluate the politics of the state against the brigands.

The first time Deli Kadri made quite a name for himself was in 1803, when he rescued the famous bandit Kara Feyzi from the Ottoman army. In the same year, Deli Kadri, who dragged down the Ottoman army in Malkara, began to become a bandit that was closely followed by Istanbul. Shortly afterwards, he was pressured in Kavaklı by the forces sent from Istanbul, but Deli Kadri and his bandits, who had benefited from the tactical mistakes of the Ottoman army and the severe winter conditions, had escaped from this blockade and had acted in an intense banditry on in Silivri-Çorlu territories. His killing of the Crimean Giray Han of the Crimean Dynasty had infuriated Sultan Selim and the sultan tasked the famous ayan of the time Serezli (Serres) Ismail with the capture of Deli Kadri. Also a number of edicts (ferman) were sent to Edirne and surrounding areas, mentioning that Deli Kadir must be executed wherever he was found. In response to these measures taken by Istanbul, Deli Kadri allied with Kara Feyzi, whom he had helped previously, and adopted as a strategy to be in constant action. In the summer of 1805, the attempt to attack the Ottoman navy around Tekfurdağ (Tekirdağ) caused an indignation in Istanbul; III. Selim tried to enchain Kadri, who had become almost impossible to capture, with a classic method: settlement policy. Following the Navy incident, a new mission was given to Serezli Ismail for remitting and the settlement of the Deli Kadri in Bergos and its surroundings. Serezli Ismail, who managed to personally meet with Deli kadri, carried out this task and made it possible for Deli Kadri to be placed in Bergos and his men in Hayrabolu. Deli Kadri, who made the banditry a way of life, continued to loot for a while without holding his promise, but finally was willing to reside in Bergos. Thus, Deli Kadri began to be referred to as Abdulkadir, the Ayan of Bergos and he was assigned to provide peace of the region and even took part in the struggle with some local bandits. But after the rebellion of the Serbs in the region in 1806, there was a war with Russia and this was an opportunity for Deli 
Kadri to return to banditry. Though once again he was forgiven during this time, the things he did during the war were perceived as betrayal to the empire; In November of 1807, the governor of Rumelia, Hurşit Paşa killed Deli Kadri. Thus, Deli Kadri case which for around a decade caused a lot of trouble in Bergos territory was closed.

The struggle of the empire with Deli Kadri, especially in the last five years, reflected the portrait of the bandits-state relationship quite well in general. The situation of the central authority across an ordinary mountain bandit was not only characteristic of Deli Kadri. Although the struggle with Deli Kadri contains some special conditions, it seems to be important in terms of revealing the general reflexes of the empire in relation to the state-bandit. Hence as well as the unique baldness of Deli Kadri, the problematic politics of the empire was influential in the long-term failure of this struggle. One of the most important advantages of Deli Kadri against the Ottoman soldiers was the ability to move quickly, setting fear around him as a strategy. He also knew the region very well and seemed knowledgeable in terms of military strategy. His hiding and fortified places were either very mountainous, such as the Ottoman horsemen could not enter, or were quite flat and wide, where they would become open targets when they entered. In the meantime, the weaknesses of the Ottoman armies were also revealed. They could not make out when and how Deli Kadri would move, and the information received in the intelligence was often false. From the point of view of the empire, some of the important problems in struggle with the mountainous bandits were the transfer and administration of the army. There were not enough cavalry units to make the bandit follow-up swiftly. On the other hand, increasing the number of soldiers brought along with itself the problem of ammunition and subsistence during long-running bandit chase. As understood from the documents, the staff officers assigned with bandit chase did not dare to make decisions at their own in critical moments, and even when they did, they usually planned on the wrong tactics. Finally, the lack of coordination between the army and the ayans, which had an important mission chasing the bandits, led to the failure of military movements in general. 


\section{KAYNAKÇA}

Arşiv Belgeleri

\section{Şeriye Sicilleri(MŞH.ŞSC.d)}

Rodosçuk Şeriye Sicili

No: 7427.

\section{Mühimme Defterleri (A.DVN.MHMd.)}

No: 219 ve 223

\section{Başbakanlık Osmanlı Arşivi (BOA)}

BOA.A.E.SSLM. III 30-1738 (29 Z 1218/10 Nisan 1804); 67-4042 (29 Z 1210/5 Temmuz 1796); 132-8026 (21 Ra 1219/30 Haziran 1804); 142-8573 (21 Ra 1214/23 Ağustos 1799); 17110166 (29 Z 1218/10 Nisan 1804); 199-11941 (29 Z 1218/10 Nisan 1804); 339-19563 (29 Z 1218/10 Nisan 1804); 372-21224 (29 Z 1218/10 Nisan 1804); 372-21225 (29 Z 1218/10 Nisan 1804); 401-23110 (10 Ca 1220/6 Ağustos 1805).

BOA.AE.SABH.I. 26-2001 (7 R 1196/22 Mart 1783); 136-9178 (26 Za 1193/4 Ocak 1780)

BOA.C.ZB 7-319 (18 N 1218/1 Ocak 1804); 8-368 (5 Za 1196/12 Ekim 1782); 9-446 (23 N 1218/6 Ocak 1804); 11-530 (5 C 1220/31 Ağustos 1805); 23-1105 (29 Ş 1218/14 Aralık 1803); 251215 (15 M 1215/8 Haziran 1800); 28-1365 (29 Z 1218/10 Nisan 1804); 50-2499 (29 L 1220/20 Ocak 1806); 76-3778 (21 Ş 1218/6 Aralık 1803).

BOA.C.AS 27-1240 (11 S 1221/30 Nisan 1806); 104-4096 (6 Ş 1221/19 Ekim 1806); 133-5012 (18 L 1221/29 Aralık 1806); 192-8280 (18 Ca 1215/7 Ekim 1800); 1053-46287 (1 B 1221/14 Eylül 1806); 1222-54853 (29 M 1222/8 Nisan 1807).

BOA.C.DH 27-1332 (7 Ca 1220/3 Ağustos 1805); 52-2583 (29 L 1218/11 Şubat 1804); 109-5444 (10 N 1218/24 Aralık 1803); 137-6814 (7 N 1222/8 Kasım 1807); 303-15123 (29 N 1214/24 Şubat 1800).

BOA.HAT 46-2264 (29 Z 1218/10 Nisan 1804); 48-2310 (29 Ra 1220/27 Haziran 1805); 48-2310A (29 Ra 1220/27 Haziran 1805); 48-2312 (29 Z 1220/20 Mart 1806); 49-2324 (25 Ra 1219/4 Temmuz 1804); 49-2347 (6 R 1219/15 Temmuz 1804); 49-2348-C (13 Ra 1219/22 Haziran 1804); 51-2385 (29 Z 1218/10 Nisan 1804); 52-2456 (25 C 1218/12 Ekim 1803); 53-2485 (2 B 1218/18 Ekim 1803); 53-2478 (10 Za 1219/10 Şubat 1805); 54-2502-A (18 B 1218/3 Kasım 1803); 54-2502-C (17 B B 1218/2 Kasım 1803); 55-2535 (13 N 1218/27 Aralık 1803); 55-2552 (29 Z 1219/31 Mart 1805); 56-2563 (29 Z 1219/31 Mart 1805); 56-2565 (29 Z 1219/31 Mart 1805); 56-2567 (5 Ra 1219/14 Haziran 1804); 56-2568 (20 N 1218/3 Ocak 1804); 57-2590 (9 Za 1219/9 Şubat 1805); 57-2591 (2 Z 1219/4 Mart 1805); 57-2599 (8 Z 1219/10 Mart 1805); 57-2606 (3 Ra 1220/1 Haziran 1805); 57-2615-A (15 B 1218/31 Ekim 1803); 57-2615-B (15 B 1218/31 Ekim 1803); 57-2615-C (15 B 1218/31 Ekim 1803); 57-2616 (5 Ra 1219/14 Haziran 1804); 57-2616-B (3 Ra 1219/12 Haziran 1804); 57-2618 (14 B B 1218/30 Ekim 1803); 572618-C (14 B B 1218/30 Ekim 1803); 57-2618-D (14 B 1218/30 Ekim 1803); 58-2627 (29 Z 1218/10 Nisan 1804); 58-2627-D (29 Z 1218/10 Nisan 1804); 58-3630-A (24 N 1220/16 Aralık Ağustos 1805); 59-2637 (15 B 1218/31 Ekim 1803); 59-2660 (7 M 1221/27 Mart 1806); 59-2660-A (7 M 1221/27 Mart 1806); 59-2660-B (7 M 1221/27 Mart 1806); 59-2660-C (12 M 1221/1 Nisan 1806); 69-2921-A (28 Ra 1219/7 Temmuz 1804); 69-2923 (2 Ra 1219/11 Haziran 1804); 72-3023 (20 Ş 1218/5 Aralık 1803); 72-3026-A (13 Ra 1219/22 Haziran 1804); 73-3038 (3 C 1220/29 Ağustos 1805); 75-3101 (29 Z 1220/20 Mart 1806); 77-137 (21 L 1218/3 Şubat 1804); 78-3231 (4 Za 1220/24 Ocak 1806); 78-3257 (25 R 1220/23 Temmuz 1805); 79-3268 (25 R 1220/23 Temmuz 1805); 84-3462 (20 Za 1219/20 Şubat 1805); 1044096 (6 Ş 1221/19 Ekim 1806); 120-4860 (11 Ca 1221/27 Temmuz 1806); 136-5571 (29 Z 1218/10 Nisan 1804); 150-6316-G (29 M 1221/18 Nisan 1806); 150-6330 (29 Ra 1221/16 Haziran 1806); 150-6333 (13 Ra 1221/31 Mayıs 1806); 214-11762 (6 L 1218/19 Ocak 1804); 216-11836 (10 Ş 1218/25 Kasım 1803); 216-11836-B (29 Z 1218/10 Nisan 1804); 218-12000 (2 B 1218/18 Ekim 1803); 218-12016 (20 Ş 1218/5 Aralık 1803); 218-12031 (7 B 1218/23 
Ekim 1803); 255-14502 (29 Z 1220/20 Mart 1806); 3358-A (30 N 1218/13 Ocak 1804).

\section{Osmanlı Tarihleri}

Ahmet Cevdet Paşa (1871), Tarih-i Cevdet, İstanbul: Matbaa-i Amire.

Câbî Ömer Efendi (2003), Câbî Târihi (Târih-i Sultân Selîm-i Sâlis ve Mahmûd-ı Sânî) Tahlîl ve Tenkidli Metin, I, (haz. Mehmet Ali Beyhan), Ankara: TTK.

Mütercim Ahmed Âsım Efendi (2015), Âsım Efendi Tarihi, I-II (1218-1224/1804-1809) (haz. Ziya Yılmazer), İstanbul: Türkiye Yazma Eserler Kurumu Başkanlığı No: 58.

\section{Gazeteler}

Journal de l'empire, 14 Temmuz 1807.

Journal des débats et des décrets, 25 Nisan 1805.

\section{Araştırma Eserleri}

ALTUNAN, Sema (2006), “XVII.Yüzyıl Sonlarında İstanbul-Edirne Arasındaki Menziller ve Bazı Menzilkeş Köyler", Tarih Araştırmaları Dergisi, 25 (39): 75-99.

AYGÜN, Necmettin (2010), “Gümülcine Ayânı Tokadcıklı Süleyman (1761-1804)”, Belleten, LXXIV (271): 707-768.

BARDAKOĞLU, Ali (1995), “Eşkıya”, DİA, C. XI, İstanbul: TDV, 463-466.

BAŞER, Alper (2006), Gümülcine Ayanı Tokatcıklı Süleyman Ağa ile Ferecik Ayanı Ali Molla'nın Faaliyetleri ve Merkezi Hükümetle Olan İlişkileri, Afyonkarahisar: Afyon Kocatepe Üniversitesi, Sosyal Bilimler Enstitüsü, (Basılmamış Yüksek Lisans Tezi).

BEYDİLLİ, Kemal (2007), “Pazvandoğlu Osman”, DIA C. XXXIV, İstanbul: TDV, 208-210.

BEYDİLLİ, Kemal (2009), “Selim III”, DİA, C. XXXVI, İstanbul: TDV, 421-425.

DRIAULT, Édouard (2013), Napoléon'un Şark Siyâseti, Selîm-i Sâlis, Napoléon, Sébastiani ve Gardane, (Tercüme: Köprülüzâde Fuad, Çeviriyazı: Selma Günaydın), Ankara: TTK.

EKİNCİ, İlhan (2013), "Karadeniz'de Âyanlar ve Denizcilik", Karadeniz Araştırmaları, Balkan, Kafkas, Doğu Avrupa ve Anadolu Incelemeleri Dergisi, 10 (37): 15-50.

ESMER, Tolga Uğur (2014), "The Precarious Intimacy of Honor in Late Ottoman Accounts of Para-militarism and Banditry", European Journal of Turkish StudiesSocial Sciences on Contemporary Turkey, (18): 1-18.

İLGÜREL, Mücteba (1995), “Eşkıya, Osmanlılarda Eşkıyalık Hareketleri”, DİA, XI, İstanbul: TDV, 1995, 466-469.

JORGA, Nicolea (1914), Histoire des États balcanique à l'époque moderne, Bucarest: Librairie C. Sfetea.

JORGA, Nicolea (2005), Osmanlı İmparatorluğu Tarihi, 5, (çev. Nilüfer Epçeli), İstanbul: Yeditepe.

KARAL, Enver Ziya (1942), Selim III'ün Hatt-ı Humayunları, Ankara: TTK.

ÖZKAYA, Yücel (1983), Osmanl Imparatorluğunda Dağhı İsyanları (1791-1808), Ankara: AÜDTCF Yayınları No: 344.

UZUNÇARŞILI, İsmail Hakkı (1971), "Nizam-1 Cedit Ricalinden Kadı Abdurrahman Paşa", Belleten, XXXV (138): 245-302.

UZUNÇARŞILI, İsmail Hakkı (2010), Meşhur Rumeli Âyanlarından Tirsinikli İsmail, Yıllık Oğlu Süleyman Ağalar ve Alemdar Mustafa Paşa, Ankara: TTK.

YAVUZ, Ali (2010), Vidin Ayanı Pazvantoğlu Osman'ın Faaliyetleri ve Merkezi Hükümetle İlişkileri, Afyonkarahisar Afyon Kocatepe Üniversitesi, Sosyal Bilimler Enstitüsü (Basılmamış Yüksek Lisans Tezi).

YAYCIOĞLU, Ali (2015), Partners of the Empire, The Crisis of the Ottoman Order in the Age of Revolutions, California: Stanford University Press.

YILDIZ, Aysel (2017), Crisis and Rebellion in the Ottoman Empire, the Downfall of a Sultan in the Age of Revolution, New York and London: I.B. Tauris. 